\title{
BIOMASS AND PRIMARY PRODUCTION OF EUROPEAN BEECH (FAGUS SYLVATICA L.) STANDS IN UKRAINIAN CARPATHIANS
}

\author{
Vasylyshyn R. D., Lakyda I. P.
}

\section{INTRODUCTION}

Forests of Ukrainian Carpathians are among the important environment stabilizing factors in mountainous ecosystems of the region. They serve as a main mean for sustaining environmental stability. Forest plant communities of the studied region feature important climate regulative, water flow regulative, water protective, soil protective, sanitary and hygienic, and other ecosystem services ${ }^{1,2}$. The mentioned sphere of forestry-related research elaborates ideas of V.I. Vernadskyi and H.M. Vysotskyi. Well-known scientists have worked in this sphere, namely P.S. Pasternak ${ }^{3}$, S.A. Hensiruk ${ }^{4,5,6}$, S.M. Stoiko ${ }^{7,8}$, V.S. Oliinyk ${ }^{9}$, Ya.A. Saban ${ }^{10}$, K.K. Smahliuk ${ }^{11}$, I.F. Kalutskyi ${ }^{12}$ and many others ${ }^{13,14}$.

\footnotetext{
${ }^{1}$ Василишин Р.Д. Ліси Українських Карпат: особливості росту, біологічна та енергетична продуктивність. Монографія. Київ : ТОВ «ЦП «Компринт», 2016. 418 с.

2 Василишин Р.Д. Еколого-енергетичний потенціал лісів Українських Карпат та його стале використання. Монографія. Київ : ТОВ «ЦП «Компринт», 2018. 303 с.

3 Пастернак П.С. Горные леса Украинской. Москва : Лесн. пром-сть, 1979. C. $105-118$.

${ }^{4}$ Генсірук С.А. Ліси Українських Карпат та їх використання. Київ : Урожай, 1964. $290 \mathrm{c}$.

${ }^{5}$ Генсірук С.А. Ліси України. Київ : Наук. думка, 1992. 408 с.

${ }^{6}$ Генсірук С.А., Нижник М. С., Копій Л. І. Ліси Західного регіону України. Львів : Атлас, 1998. 408 с.

7 Стойко С.М. Наслідки антропогенної трансформації лісових екосистем Карпат та шляхи елімінації шкідливих екологічних процесів. Украӥнський ліс. 1993. № 2. C. 11-17.

${ }^{8}$ Стойко C.M. Причини катастрофічних паводків у Закарпатті та системи екологічних профілактичних заходів їх попередження. Український ботанічний журнал. 2000. Т. 57, № 1. С. 11-20.

${ }^{9}$ Олійник В.С. Методичні особливості вивчення і оцінки гідрологічної ролі гірських лісів Карпат. Науковий вісник Національного аграрного університету. 2000. Вип. 25. С. 159-166.

10 Сабан Я.А. Продуктивность и возобновление леса в горных условиях. Львов : Выща школа, 1988. 144 с.
} 
V.I. Parpan ${ }^{15}$ claims that research of biosphere functions of forests in the Carpathians shall rest upon the main principles of the modern paradigm of mountain silvics, silviculture, and sustainable forestry.

An integral part of the environmental component of mountain forestry should be a monitoring system capable of ensuring operational control over the state of the environment. This will make it possible to develop long-term forecasting models of changes in the state of forests, taking into account trends in their development and global climate change ${ }^{16}$.

Carpathian forests as a type of vegetation, in particular European beech stands, play a major regional role in the accumulation of solar energy in the biotic energy cycle of the biosphere and in the processes of oxygen production and sequestration of carbon emitted from various sources. Due to their vertical structure and significant territorial distribution, the forest plant communities of the region have important buffering properties, i.e. they act as a kind of boundary strip between the atmosphere and the lithosphere. Therefore, they have a critical role among other types of vegetation in the transformation of precipitation, heat fluxes and the main geochemical cycles of natural ecosystems. Such properties determine the most active environment-forming and protective functions of forests and help maintain a stable natural balance both in forested areas and in neighboring landscapes ${ }^{17}$.

11 Смаглюк К.К. Оценка экологических последствий хозяйственного преобразования горных лесов Карпат. Лесоведение. 1978. № 2. С. 3-9.

12 Калуцький І.Ф. Вітровали на північно-східному макросхилі в Українських Карпатах. Монографія. Львів : Манускрипт, 1998. 204 с.

13 Лакида П.І., Бокоч В.В., Василишин Р.Д., $\quad$ Терентьєв А.Ю. Біопродуктивність лісових фітоценозів Карпатського національного природного парку. Монографія. Корсунь-Шевченківський

ФОП Гавришенко В. М., 2015. 154 с.

14 Каганяк Ю.Й.Структура поколінь лісу різновікових букових деревостанів північно-східного мегасхилу Карпат. Наукові праці лісівничої академії наук України. 2011. Вип. 9. С. 118-120.

15 Парпан B.I. Концептуальні засади гірського лісознавства та лісівництва. Науковий вісник Національного лісотехнічного університету Украйни. 2013. Вип. 23.5. С. 22-28.

16 Василишин Р.Д., Домашовець Г.С., Василишин О.М. Біопродуктивність та депонований вуглець штучних модальних букових деревостанів Українських Карпат. Науковий вісник Національного лісотехнічного університету. 2013. Вип. 23.11. С. 14-19.

17 Швиденко А.3., Лакида П.І., Щепащенко Д.Г., Василишин Р.Д., Марчук Ю.М. Вуглець, клімат та землеуправління в Україні: лісовий сектор. Монографія. Корсунь-Шевченківський : ФОП Гавришенко В. М., 2014. 283 с. 
Currently, more than 260 million tons of carbon, or about a third of the amount for the whole Ukraine, have been accumulated in the forests of the Ukrainian Carpathians. At the same time, Carpathian forests have the highest density of sequestered carbon per unit area of forested plots compared to other regions ${ }^{18}$. The values of this index range from 11 to $40 \mathrm{~kg} \mathrm{C} \cdot\left(\mathrm{m}^{2}\right)^{-1}$.

The share of forest cover in Ukrainian Carpathians is significantly higher than in other regions of the country (Fig. 1). Over $20 \%$ of forest areas of Ukraine are covered with forest vegetation, and forests, which cover an area of 2085.6 thousand hectares, are the main factor in maintaining the ecological balance of the region and, among others, play an important hydrological role.

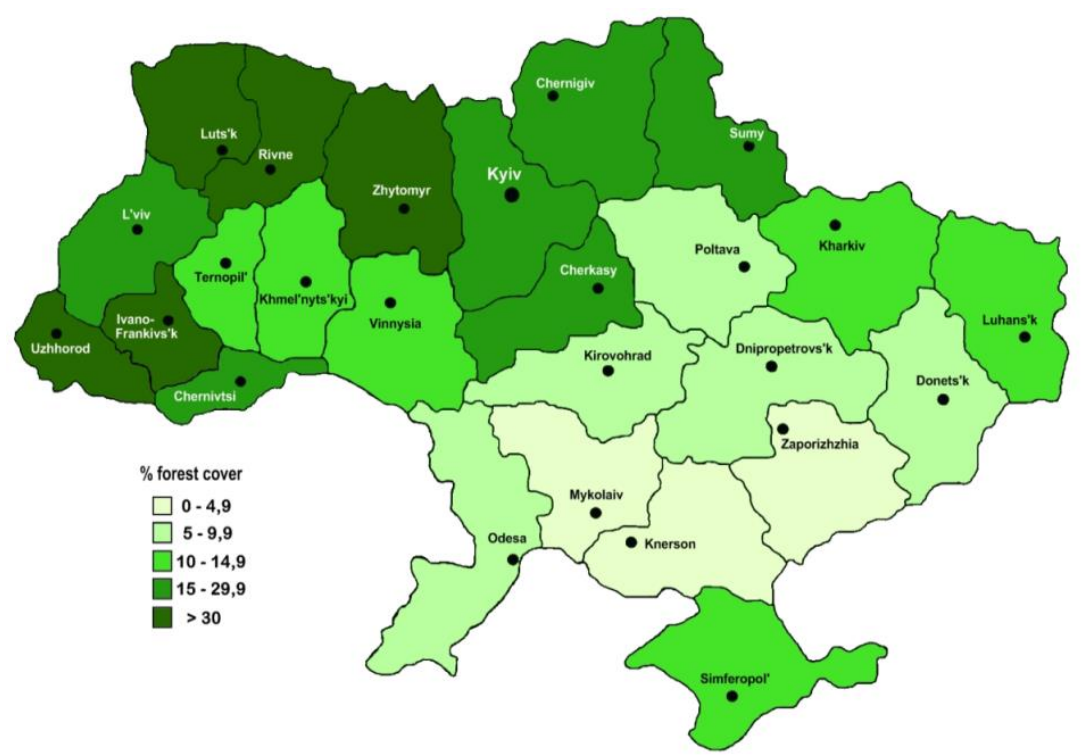

Fig. 1. Percent of cover in Ukraine by oblasts (administrative regions) ${ }^{19}$

This feature of forest plant communities is formed as a result of moisture regulation by the system "forest stand - soil" (water-regulative

\footnotetext{
18 Василишин Р.Д. Ліси Українських Карпат: особливості росту, біологічна ra енергетична продуктивність. Монографія.

Київ ТОВ «ЦП «Компринт», 2016. 418 с.

${ }^{19}$ Lakyda P., Geletukha G., Vasylyshyn R. et. all. Energy potential of biomass in Ukraine. Kyiv : Publishing Center of NUBiP of Ukraine, 2011. 28 p.
} 
properties). The positive consequences of this process result in an increase of groundwater resources (water protective role) and reduction of slope water flows, as well as a uniform return of moisture to the channel network (flow regulative role).

European beech stands in the region, which cover an area of almost 680 thou. hectares, are a key factor not only in the formation of biodiversity of forest ecosystems in Ukrainian Carpathians, but also perform important ecosystem functions, including energy accumulative, carbon sequestrative and oxygen productive. The evaluation of the mentioned functions is based on quantitative indices of biomass of studied stands, taking into account the intensity of bioproduction process on the basis of primary production.

\section{Silvicultural and biometric characteristics of European beech stands in Ukrainian Carpathians}

Silvicultural and biometric characteristics of European beech stands are presented on the basis of the industrial relational database "Stand level biometric characteristics of forests", which is operated by Industrial Association "Ukrderzhlisproekt". The database contains a detailed biometric characteristics of stands composed by dominant forest-forming tree species according to the current state forest account ${ }^{20}$. According to the mentioned information resource, the forests of Ukrainian Carpathians cover an area of over 2 million hectares with standing stock of about 580 million $\mathrm{m}^{3}$ (Table 1 ).

Table 1

Distribution of area and growing stock of stands of the main forest-forming tree species in Ukrainian Carpathians

\begin{tabular}{|c|c|c|}
\hline Tree species & Area, thou. ha & Growing stock, Mio $\mathbf{~ m}^{\mathbf{3}}$ \\
\hline Norway spruce & 591,6 & 199,3 \\
\hline Silver fir & 129,7 & 36,0 \\
\hline European beech & 674,8 & 217,0 \\
\hline Other tree species & 616,2 & 125,2 \\
\hline Total & 2012,3 & 577,5 \\
\hline
\end{tabular}

20 Довідник лісового фонду України [укладений спеціалістами виробничотехнологічного відділу ВО «Укрдержліспроект» за матеріалами державного обліку лісів станом на 01.01.2011р.]. Ірпінь: ВО «Укрдержліспроект», 2012. 130 с. 
European beech (Fagus sylvatica L.) - one of the most widespread tree species in the flora of Ukrainian Carpathians. It forms pure and mixed (with oak, hornbeam, spruce, fir, and birch) stands in the altitude range from 300 to $1300 \mathrm{~m}$ above sea level. This is a shade-tolerant species that can be depressed during a long time, and therefore often in mixed forests, beech grows in the second layer under the canopy of dark conifers. European beech is common in the plains and mountains of the country. Mountain beech forests are a unique phenomenon. First of all, science considers them as an environmental and climate-regulating factor. Their destruction can lead to negative, even catastrophic, irreversible global changes.

Quantitative parameters of distribution of the mentioned tree species within the administrative regions in Ukrainian Carpathians is presented in Table 2.

Table 2

Distribution of quantitative characteristics of European beech stands by administrative regions

\begin{tabular}{|c|c|c|c|}
\hline Administrative region & $\begin{array}{c}\text { Number of } \\
\text { stands }\end{array}$ & Area, thou. ha & $\begin{array}{c}\text { Growing stock, } \\
\mathbf{M i o ~ m}^{\mathbf{3}}\end{array}$ \\
\hline Zakarpattia & 57361 & 387,3 & 129,1 \\
\hline Ivano-Frankivsk & 23592 & 111,3 & 33,8 \\
\hline Lviv & 22195 & 115,5 & 35,0 \\
\hline Chernivtsi & 8499 & 60,6 & 19,1 \\
\hline Total & 111647 & 674,8 & 217,0 \\
\hline
\end{tabular}

Nearly $57 \%$ of beech forests with a growing stock of $129.1 \mathrm{Mio} \mathrm{m}^{3}$ are located in Zakarpattia region, another $30 \%$ - in Ivano-Frankivsk and Lviv regions. In general, European beech stands in Ukrainian Carpathians cover $33.5 \%$ of the forested area in the region.

Analysis of the site index class distribution of area covered by beech stands shows that in the Carpathians highly productive stands of I-I ${ }^{\mathrm{a}}$ site index classes are the most widespread and occupy $71.4 \%$ of the total area of beech forests. Almost $20 \%$ of the area is covered by stands of II site index class, while the share of low-productive stands (site index IV and lower) does not exceed $1 \%$.

Regarding the relative stocking of European beech stands, it should be noted that medium-stocked stands are dominant. The share of stands with a relative stocking of 0.6 and 0.7 is $50.6 \%$ of the area of beech forests in the Carpathian region, while highly-stocked ( 0.9 and higher) and low-stocked ( 0.4 and lower) account for $10.5 \%$ and $3.2 \%$ respectively. At the same time, the largest representation of highlystocked European beech stands is in Zakarpattia region (6.8\%). 
The age structure of the studied beech stands is shown in Table 3 .

The data presented in Table 3 shows that the age structure is dominated by mid-aged stands, the share of which is $56 \%$. Almost $20 \%$ are mature and overmature stands.

Table 3

Distribution of quantitative characteristics of beech stands by administrative regions and age classes

(numerator - area, ha; denominator - growing stock, thou. $\mathbf{m}^{\mathbf{3}}$ )

\begin{tabular}{|c|c|c|c|c|c|}
\hline \multirow[b]{2}{*}{$\begin{array}{l}\text { Age } \\
\text { class }\end{array}$} & \multicolumn{4}{|c|}{ Administrative region } & \multirow[b]{2}{*}{ Total } \\
\hline & Zakarpattia & $\begin{array}{c}\text { Ivano- } \\
\text { Frankivsk }\end{array}$ & Lviv & Chernivtsi & \\
\hline \multirow{2}{*}{ I } & 7162,0 & 1181,6 & 1674,2 & 1619,7 & 11637,5 \\
\hline & 123,7 & 13,3 & 26,1 & 15,9 & 179,0 \\
\hline \multirow{2}{*}{ II } & 15509,2 & 2871,2 & 2747,0 & 2347,9 & 23475,3 \\
\hline & 1042,2 & 106,9 & 108,2 & 99,5 & 1356,8 \\
\hline \multirow{2}{*}{ III } & 32901,4 & 3052,3 & 3006,6 & 1253,2 & 40213,5 \\
\hline & 5757,5 & $\overline{494,9}$ & 294,3 & $\overline{125,9}$ & 6672,6 \\
\hline \multirow{2}{*}{ IV } & 26413,2 & 3206,9 & $\underline{3457,6}$ & 1587,9 & 34665,6 \\
\hline & 6424,7 & $\overline{798,6}$ & $\overline{572,3}$ & $\overline{276,2}$ & 8071,8 \\
\hline \multirow{2}{*}{ V } & 25211,4 & 6313,1 & 6097,8 & 3479,4 & 41101,7 \\
\hline & $\overline{7100,8}$ & $\overline{1674,4}$ & $\overline{1354,1}$ & $\overline{898,6}$ & $\overline{11027,9}$ \\
\hline \multirow{2}{*}{ VI } & $\underline{51741,4}$ & 17604,5 & 13243,8 & $\underline{5174,3}$ & $\underline{87764,0}$ \\
\hline & 18043,2 & $\overline{5221,2}$ & 3829,2 & $\overline{1586,9}$ & 28680,5 \\
\hline \multirow{2}{*}{ VII } & $\underline{36061,6}$ & 16851,4 & 18747,1 & 7009,4 & 78669,5 \\
\hline & 13468,0 & $\overline{5173,0}$ & $\overline{5866,6}$ & $\overline{2300,8}$ & 26808,4 \\
\hline \multirow{2}{*}{ VIII } & 34030,1 & 17043,0 & 19707,1 & $\underline{8820,0}$ & 79600,2 \\
\hline & 13661,6 & 5675,1 & 6734,5 & 3136,4 & 29207,6 \\
\hline \multirow{2}{*}{ IX } & 24459,1 & 12004,3 & 13454,6 & 9866,8 & 59784,8 \\
\hline & 10160,3 & 4142,4 & 4564,7 & 3669,6 & 22537,0 \\
\hline \multirow{2}{*}{$\mathrm{X}$} & 21005,5 & 9516,6 & 9630,8 & 6062,6 & 46215,5 \\
\hline & 8799,8 & $\overline{3285,2}$ & $\overline{3361,6}$ & $\overline{2236,1}$ & $\overline{17682,7}$ \\
\hline \multirow{2}{*}{ XI } & 16879,2 & 7179,7 & $\underline{8794,8}$ & 7019,2 & $\underline{39872,9}$ \\
\hline & $\overline{6965,7}$ & $\overline{2414,8}$ & $\overline{3069,6}$ & $\overline{2479,8}$ & $\overline{14929,9}$ \\
\hline \multirow{2}{*}{ XII } & 10893,2 & 4042,7 & $\underline{5851,4}$ & $\underline{3044,0}$ & 23831,3 \\
\hline & $\overline{4420,3}$ & $\overline{1351,4}$ & $\overline{2076,4}$ & $\overline{1069,5}$ & $\overline{8917,6}$ \\
\hline \multirow{2}{*}{ XIII } & 7413,4 & $\underline{3397,0}$ & 3340,1 & 1322,8 & 15473,3 \\
\hline & $\overline{2880,7}$ & 1153,8 & 1175,9 & 470,5 & 5680,9 \\
\hline \multirow{2}{*}{$\begin{array}{l}\text { XIV } \\
\text { and } \\
\text { older }\end{array}$} & 77659,9 & 7013,0 & 5767,1 & 2005,8 & 92445,8 \\
\hline & 30272,8 & 2291,1 & 2002,5 & 726,3 & 35292,7 \\
\hline \multirow[b]{2}{*}{ Total } & $\underline{387340,6}$ & 111277,3 & 115520,0 & 60613,0 & 674750,9 \\
\hline & 129121,2 & $\frac{33796,3}{337}$ & 35035,8 & 19092,0 & 217045,3 \\
\hline
\end{tabular}


Forest typological structure has a significant influence on the efficiency of performance of ecological functions by European beech stands. European beech in the Carpathian region is widespread in fresh, moist and damp types of moisture conditions within fairly rich and rich forest growth conditions. European beech acts as forest-forming tree species in fairly rich and rich site types, where it occupies 40.4 and $59.5 \%$ of the area covered with forest vegetation (Table 4 ).

Table 4

\section{Distribution of area of European beech stands by administrative} regions and types of forest growth conditions, ha

\begin{tabular}{|c|c|c|c|c|c|}
\hline \multirow{2}{*}{$\begin{array}{c}\text { Administrative } \\
\text { region / } \\
\text { Site fertility types }\end{array}$} & \multirow{6}{*}{ Total } & fresh & moist & damp & wet \\
\hline \multicolumn{7}{|c|}{ fairly infertile site types } \\
\hline Zakarpattia & 16,8 & - & 16,8 & - & - \\
\hline Ivano-Frankivsk & 187,6 & 134,2 & 53,4 & - & - \\
\hline Lviv & 119,0 & 22,5 & 95,3 & - & 1,2 \\
\hline Chernivtsi & 97,1 & 63,5 & 33,6 & - & - \\
\hline \multicolumn{7}{|c|}{ fairly fertile site types } \\
\hline Zakarpattia & 153521,2 & 32277,6 & 121238,9 & 3,0 & 1,7 \\
\hline Ivano-Frankivsk & 69802,8 & 4615,3 & 65104,5 & 83,0 & - \\
\hline Lviv & 32686,9 & 4676,8 & 27997,0 & 13,1 & - \\
\hline Chernivtsi & 16773,3 & 2968,1 & 13780,4 & 24,8 & - \\
\hline \multicolumn{7}{|c|}{ fertile site types } \\
\hline Zakarpattia & 233802,6 & 59800,0 & 173993,2 & 4,9 & 4,5 \\
\hline Ivano-Frankivsk & 41286,9 & 8788,2 & 32489,6 & 9,1 & - \\
\hline Lviv & 82714,1 & 25030,2 & 57679,8 & 4,1 & - \\
\hline Chernivtsi & 43742,6 & 19879,8 & 23844,2 & 6,3 & 12,3 \\
\hline \multicolumn{7}{|c|}{ total within the region } \\
\hline $\begin{array}{c}\text { Fairly infertile site } \\
\text { types }\end{array}$ & 420,5 & 220,2 & 199,1 & - & 1,2 \\
\hline $\begin{array}{c}\text { Fairly fertile site } \\
\text { types }\end{array}$ & 272784,2 & 44537,8 & 228120,8 & 123,9 & 1,7 \\
\hline $\begin{array}{c}\text { Fertile site types } \\
\text { Fyyyyy}\end{array}$ & 401546,2 & 113498, & 288006,8 & 24,4 & 16,8 \\
\hline
\end{tabular}

At the same time, beech stands occupy the biggest area in moist (76.5\%) forest growth conditions. The share of other types of conditions (fresh, damp) is about $20 \%$ of the total area of beech stands. The following forest types are the most widely represented in the region: fresh and moist fairly fertile oak-hornbeam-beech forests, moist fairly 
fertile hornbeam-beech forests, fresh and moist fairly fertile hornbeampine-beech forests, fresh and moist fertile hornbeam-beech forests, fresh and moist fertile oak-hornbeam-beech forests, fresh and moist fertile firbeech forests, moist fertile hornbeam-fir-beech forests. The most productive beech stands grow in the conditions of fresh fertile oakhornbeam-beech forests and moist fertile fir-beech forests.

The mean age of beech stands in the Carpathians is 78 years, which is almost two age classes older than the corresponding values of spruce and fir stands (Table 5). However, in terms of mean growing stock of stands per 1 ha, they are slightly inferior to spruce stands.

The data in Table 5 shows that the studied stands within the administrative regions have close mean values of relative stocking, which varies in the range of 0.66-0.69. Insignificant variation of relative stocking testifies that the specified stands are formed under the influence of typical intensive forest management activities.

Table 5

\section{Mean biometric indices of beech stands within administrative regions}

\begin{tabular}{|c|c|c|c|c|c|}
\hline \multirow[b]{2}{*}{$\begin{array}{l}\text { Administrative } \\
\text { region }\end{array}$} & \multicolumn{5}{|c|}{ Mean biometric indices } \\
\hline & $\begin{array}{l}\text { age, } \\
\text { years }\end{array}$ & $\begin{array}{c}\text { diameter, } \\
\text { cm }\end{array}$ & $\begin{array}{c}\text { height, } \\
\text { m }\end{array}$ & $\begin{array}{l}\text { relative } \\
\text { stocking }\end{array}$ & $\begin{array}{c}\text { growing stock, } \\
\mathbf{m}^{3} \cdot \mathbf{h a}^{-1}\end{array}$ \\
\hline Zakarpattia & 81 & 27,9 & 22,2 & 0,69 & 333 \\
\hline Ivano-Frankivsk & 75 & 28,2 & 22,3 & 0,66 & 304 \\
\hline Lviv & 73 & 30,1 & 23,3 & 0,66 & 303 \\
\hline Chernivtsi & 76 & 29,2 & 23,1 & 0,69 & 315 \\
\hline $\begin{array}{l}\text { Average for the } \\
\text { region }\end{array}$ & 78 & 28,5 & 22,5 & 0,68 & 322 \\
\hline
\end{tabular}

In general, European beech in Ukrainian Carpathians forms pure and mixed stands of natural and artificial origin. These are mostly highly productive, medium-stocked stands, which often grow in moist, fairly fertile and fertile conditions.

The analysis of silvicultural and biometric structure of beech forests of Ukrainian Carpathians shows the presence of certain regional features of forest formations in the study region, which is significantly linked with the application of regional forest management approaches. 


\section{Potential of biomass of mountain beech forests}

The dominant component in the structure of the total biomass of mountain beech forests is their live biomass, which serves as a quantitative weight characteristic of a stand. It is not measured at practical mensurational assessment directly in the forest, but is rather calculated using mathematical models based on experimental data collected on temporary sample plots.

For modeling and assessing live biomass of mountain beech forests in Ukrainian Carpathians, data from 269 temporary sample plots (TSPs) were used, where over 600 sample trees were biometrically assessed, 183 of which included estimation of live biomass for tree crown components.

Statistical characteristics of empirical data collected on temporary sample plots that characterize the studied beech stands is presented in Table 6.

Table 6

Statistical characteristics of biometric indices of beech stands on temporary sample plots

\begin{tabular}{|c|c|c|c|c|c|c|}
\hline \multirow{2}{*}{ Index } & \multicolumn{2}{|c|}{ Value } & \multicolumn{4}{c|}{ Statistics } \\
\cline { 2 - 7 } & $\mathbf{m i n}$ & $\mathbf{m a x}$ & $\bar{X}$ & $\boldsymbol{\sigma}$ & $\boldsymbol{A}$ & $\boldsymbol{E}$ \\
\hline Age, years & 7 & 230 & 79,4 & 45,8 & 0,6 & $-0,4$ \\
\hline Diameter, cm & 1,5 & 52,0 & 24,1 & 11,8 & 0,2 & $-0,6$ \\
\hline Height, $\mathrm{m}$ & 2,6 & 39,8 & 22,4 & 7,6 & $-0,4$ & $-0,4$ \\
\hline Basal area, $\mathrm{m}^{2} \cdot \mathrm{ha}^{-1}$ & 0,7 & 64,4 & 27,1 & 7,9 & $-0,3$ & 0,4 \\
\hline Relative stocking & 0,31 & 1,23 & 0,76 & 0,2 & $-0,3$ & 0,7 \\
\hline${\text { Growing stock, } \mathrm{m}^{3} \cdot \text { ha }^{-1}}^{\mid}$ & 2,0 & 857,0 & 313,5 & 154,7 & 0,4 & 0,1 \\
\hline
\end{tabular}

In this research, the ratio between the mass of individual live biomass fractions $\left(P h_{f r}\right)$ and growing stock of stands, i.e. conversion factors, was used as a basis for modeling live biomass stocks of beech stands in Ukrainian Carpathians. Then, using growing stock of stands, which is determined independently, for example, at the time of mensurational assessment of forests, live biomass of an individual stand is calculated as the product of its growing stock and the corresponding conversion factors.

A generalized view of the mathematical expression used in the research to model the quantitative parameters of live biomass components of beech forests in Ukrainian Carpathians is as follows: 


$$
R_{v}=P h_{f r} / M=a_{0} \cdot A^{a_{1}} \cdot B^{a_{2}} \cdot P^{a_{3}} \cdot \exp \left(a_{4} \cdot A+a_{5} \cdot P\right),
$$

where $R_{v}$ - relation of mass of separate live biomass fractions of a stand (stem, wood of crown branches, foliage, roots) to its growing stock; $P h_{f r}$ - mass of separate live biomass fractions; $M$ - growing stock of a stand; $A$ - mean age of a stand, years; $B$ - site index class code; $P$ - relative stocking of a stand; $a_{1}, a_{2}, \ldots . a_{5}$ - regression coefficients.

Characteristics of the parameters of equations of ratio coefficients $R_{v}$ of live biomass fractions in beech stands are presented in Table 7.

Table 7

Parameters of equations of conversion factors' dynamics

\begin{tabular}{|c|c|c|c|c|c|c|c|}
\hline \multirow{2}{*}{$\begin{array}{l}\text { Live biomass } \\
\text { fractions }\end{array}$} & \multicolumn{6}{|c|}{ Parameters of equation } & \multirow{2}{*}{$R^{2}$} \\
\hline & $a_{0}$ & $a_{1}$ & $a_{2}$ & $a_{3}$ & $a_{4}$ & $a_{5}$ & \\
\hline $\begin{array}{l}\text { Stem over } \\
\text { bark }\end{array}$ & 0,6709 & 0,1232 & $-0,0413$ & 0,3894 & $-0,0021$ & $-0,3827$ & 0,91 \\
\hline Bark & 0,0642 & $-0,1711$ & 0,3248 & $-0,0670$ & 0,0022 & $-0,4586$ & 0,87 \\
\hline Branches & 0,2897 & $-0,4746$ & 0,9142 & 0,3390 & 0,0066 & $-0,9940$ & 0,82 \\
\hline Foliage & 0,0860 & $-1,4142$ & 0,4447 & $-2,1296$ & 0,0108 & 2,3949 & 0,81 \\
\hline Roots & 0,3696 & $-0,5612$ & 0,5132 & $-0,790$ & 0,0054 & 0,3560 & 0,45 \\
\hline $\begin{array}{c}\text { Undergrowth, } \\
\text { understorey }\end{array}$ & 0,0012 & 1,5658 & 0,6301 & $-0,3590$ & $-0,0068$ & 0,2567 & 0,65 \\
\hline $\begin{array}{l}\text { Green forest } \\
\text { floor }\end{array}$ & 0,4529 & 0,4664 & 0,5579 & 0,0064 & $-0,0023$ & $-1,0993$ & 0,56 \\
\hline
\end{tabular}

It should be noted that during the research of live biomass of beech stands such components as root systems, understorey vegetation and green forest floor were not assessed. Therefore, to estimate these components their multiple regression equations from scientific literature sources were used ${ }^{21}$. At the same time, the equations of live biomass dynamics of understorey vegetation (undergrowth, understorey, green forest floor) reflect not its relation to growing stock, but rather a direct assessment of live biomass.

Thus, the in the frame of this research regression equations that relate fractions of live biomass of forest stands with their biometric indices. Application of multidimensional dependencies allows to obtain

21 Швиденко А.З., Щепащенко Д.Г., Нильсон С., Булуй Ю.И. Таблицы и модели хода роста и продуктивности насаждений основных лесообразующих пород Северной Евразии. Москва : ОАО «Московская типография № 6», $2008.887 \mathrm{c}$. 
maximum information from research data and to some extent take into account the regional features of forest ecosystems.

The combination of the presented models with the data from the relational database "Stand level biometric characteristics of forests" allows to obtain quantitative values of live biomass stocks in European beech stands of the research region (Table 8).

Table 8

\section{Regional distribution of live biomass of beech stands in Ukrainian Carpathians}

\begin{tabular}{|c|c|c|c|c|c|c|c|c|}
\hline \multirow[b]{2}{*}{$\begin{array}{l}\text { Administrative } \\
\text { region }\end{array}$} & \multicolumn{8}{|c|}{ Live biomass by components, Mio tons } \\
\hline & 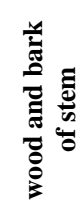 & 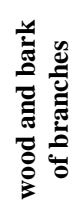 & 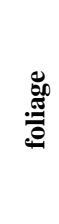 & है: & 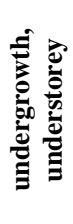 & 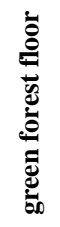 & ฮี & 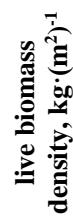 \\
\hline Zakarpattia & 70,0 & 26,9 & 1,2 & 28,4 & 1,1 & 1,3 & 128,9 & 35,9 \\
\hline Ivano-Frankivsk & 20,8 & 5,7 & 0,4 & 8,5 & 0,3 & 0,4 & 36,1 & 30,2 \\
\hline Lviv & 21,8 & 6,7 & 0,4 & 8,9 & 0,4 & 0,5 & 38,7 & 30,8 \\
\hline Chernivtsi & 10,3 & 3,2 & 0,2 & 4,0 & 0,2 & 0,2 & 18,1 & 32,3 \\
\hline Total & 122,9 & 42,5 & 2,2 & 49,8 & 2,0 & 2,4 & 221,8 & 31,8 \\
\hline
\end{tabular}

When analyzing the quantitative parameters of live biomass presented in Table 8, it becomes possible to conclude that its density in beech stands is higher than $30 \mathrm{~kg} \cdot\left(\mathrm{m}^{2}\right)^{-1}$, which is almost $70 \%$ higher than the figure for hardwood stands of Ukraine $\left(18.9 \mathrm{~kg} \cdot\left(\mathrm{m}^{2}\right)^{-1}\right)^{22}$. The variance of live biomass density of beech stands in Carpathian mountains has a clear regional character. Thus, in Zakarpattia the mentioned index equals $35.9 \mathrm{~kg} \cdot\left(\mathrm{m}^{2}\right)^{-1}$, in Bukovyna - $32.3 \mathrm{~kg} \cdot\left(\mathrm{m}^{2}\right)^{-1}$, and in Lviv and Prykarpattia - 30.8 and $30.2 \mathrm{~kg} \cdot\left(\mathrm{m}^{2}\right)^{-1}$, respectively. The distribution of the total live biomass of beech stands by age groups is presented in Table 9 .

22 Швиденко А.З., Лакида П.І., Щепащенко Д.Г., В Василишин Р.Д., Марчук Ю.М. Вуглець, клімат та землеуправління в Україні: лісовий сектор. Монографія. Корсунь-Шевченківський : ФОП Гавришенко В. М., 2014. 283 с. 
Distribution of live biomass of beech stands in Ukrainian Carpathians by age groups

\begin{tabular}{|c|c|c|c|c|c|c|}
\hline \multirow[b]{2}{*}{$\begin{array}{l}\text { Species group, } \\
\text { dominant species }\end{array}$} & \multicolumn{6}{|c|}{ Live biomass by age groups, Mio tons } \\
\hline & $\begin{array}{l}\stackrel{\infty}{0} \\
\stackrel{0}{0} \\
0\end{array}$ & 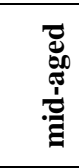 & & 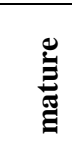 & 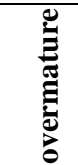 & है \\
\hline $\begin{array}{l}\text { Hardwood } \\
\text { broadleaves }\end{array}$ & 17,2 & 147,7 & 46,4 & 43,5 & 25,3 & 280,1 \\
\hline $\begin{array}{c}\text { Including } \\
\text { European beech }\end{array}$ & 8,0 & 114,0 & 38,4 & 37,4 & 24,0 & 221,8 \\
\hline
\end{tabular}

The age structure of stocks of live organic matter in bone-dry state (Table 9) is characterized by the dominance of mid-aged stands, which account for more than a half of live biomass of beech forests in the region $(51.4 \%)$, while the share of young, maturing, mature, and overmature stands is $3.6 ; 17.3 ; 16.9$ and $10.8 \%$, respectively.

The basis for forecasting live biomass stocks for mountain beech forests are reference tables of bioproductivity dynamics, developed on the site index scale basis. The scientific basis for the development of this kind of standards are models of conversion factors and mathematical dependences of dynamics of the main biometric indices of beech stands ${ }^{23}$.

Fragments of reference tables for pure and mixed beech stands of natural and artificial origin, characterized by $\mathrm{I}^{\mathrm{a}}$ site index class, which are typical for the conditions of Ukrainian Carpathians, are presented in Tables 10, 11 and 12. In this case, the reference tables for mixed stands characterize the stand as a whole, providing the share of secondary tree species.

${ }^{23}$ Василишин Р.Д. Ліси Українських Карпат: особливості росту, біологічна та енергетична продуктивність. Монографія. Київ : ТОВ «ЦП «Компринт», 2016. 418 с. 


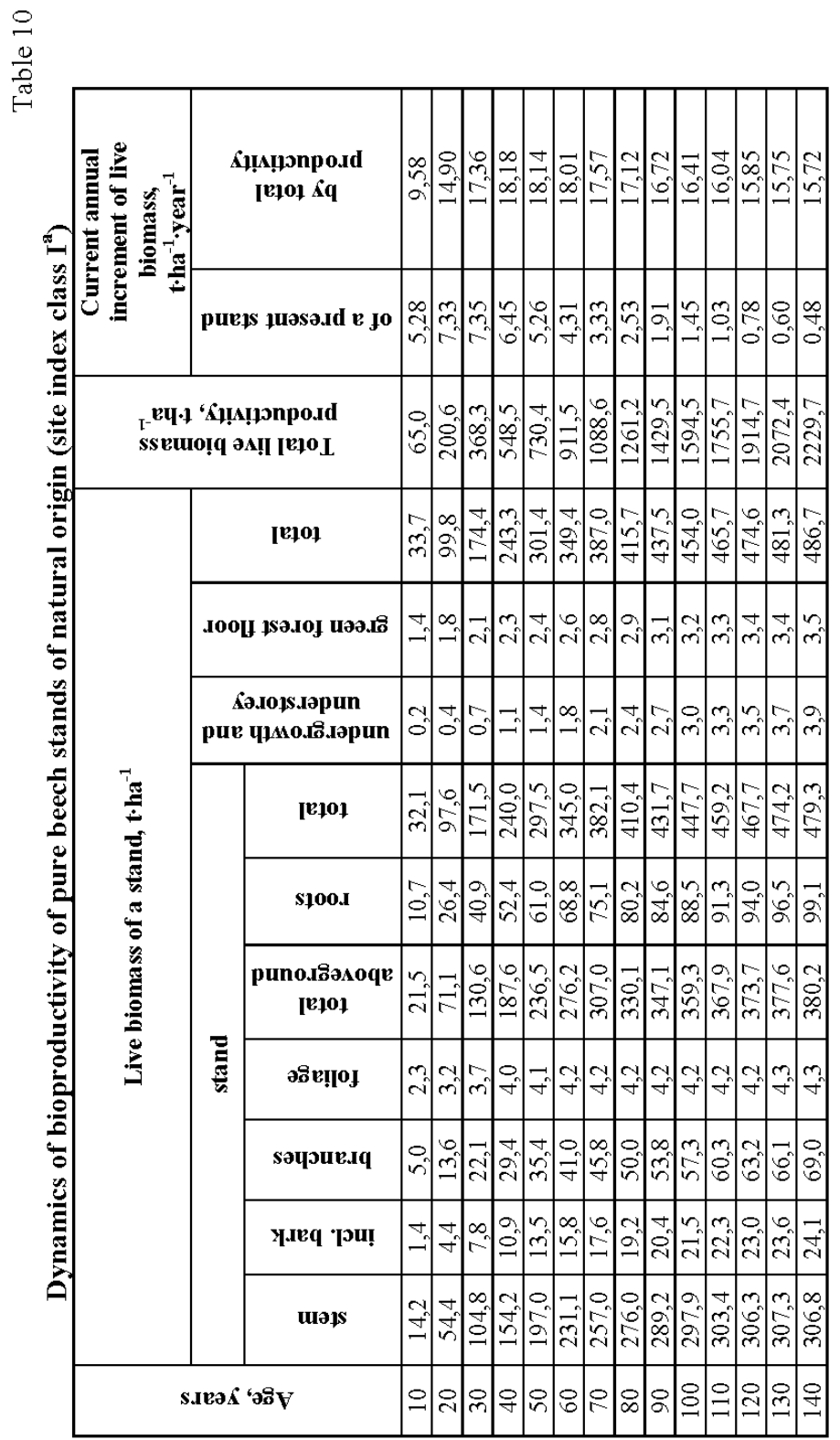


7
$\frac{0}{0}$
0
0

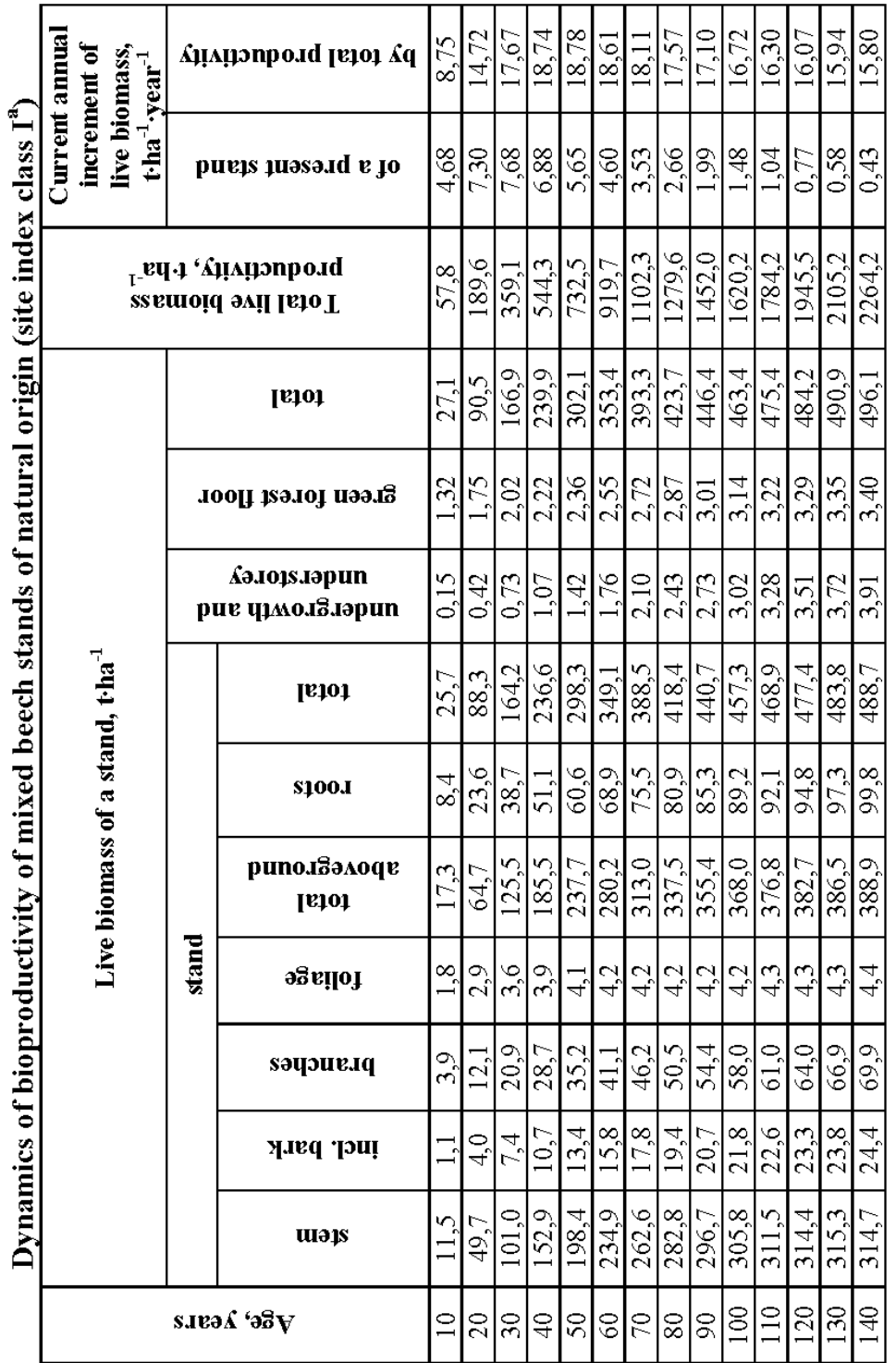


굴

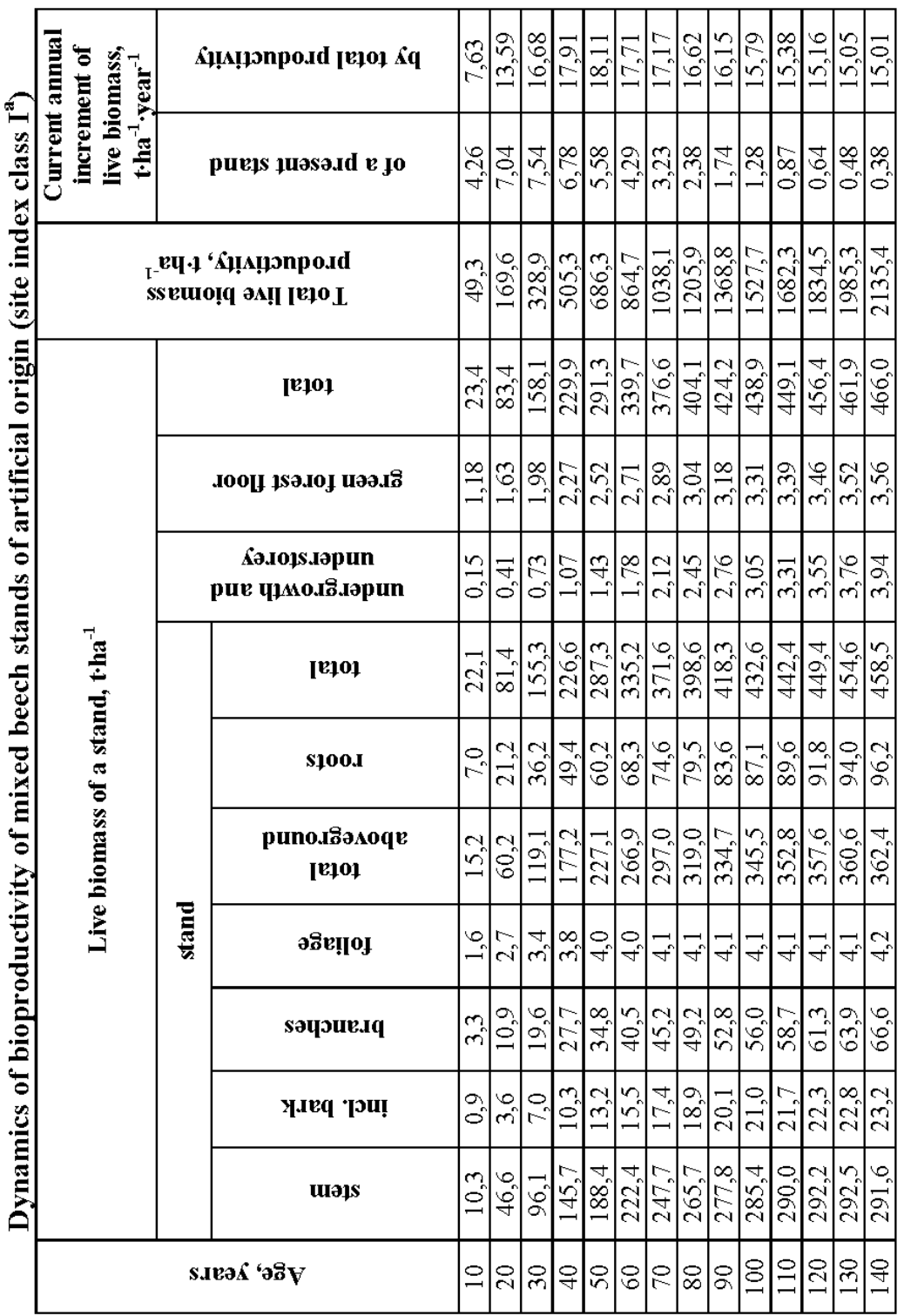


For a better understanding of the quantitative indices provided in the reference tables, it is necessary to pay attention to the meaning of such key indices as live biomass of a present stand and by total productivity of the live biomass. In this context, the first index reflects the amount of live organic matter that is present in a stand of a certain age, while the total live biomass productivity of a stand at a certain age shows the cumulative amount of all live biomass created during the existence of a stand. This is important for the practical use of the proposed tables.

Forest bioenergetics is an innovative direction of modern forestry research, which is closely related to research of bioproductivity of forest plant communities ${ }^{24}$. One of the objects in this direction is energy potential of woody biomass and optimization of its use aiming at replacing fossil fuels in compliance with the conceptual principles of sustainable development.

To assess the energy potential of woody biomass of beech stands in Ukrainian Carpathians, indices of specific energy content in live biomass components are proposed based on their basic density indices ${ }^{25}$.

Table 13

Specific energy content in live biomass components of stem and crown branches of European beech trees under conditions of Ukrainian Carpathians

\begin{tabular}{|c|c|c|c|}
\hline \multirow{2}{*}{$\begin{array}{l}\text { Live biomass } \\
\text { component }\end{array}$} & \multicolumn{3}{|c|}{$\begin{array}{l}\text { Energy content in bone-dry matter of live biomass } \\
\text { components, } \mathbf{G J} \cdot\left(\mathrm{m}^{3}\right)^{-1}\end{array}$} \\
\hline & wood & bark & wood over bark \\
\hline Stem & 10,782 & 8,690 & 10,621 \\
\hline Crown branches & 10,156 & 8,547 & 9,852 \\
\hline
\end{tabular}

In accordance with the data, presented in Table 13, it is possible to conclude that stem wood has the highest energy content. One cubic meter of this live biomass fraction, based on the analyzed index, is equivalent to $340 \mathrm{~m}^{3}$ of natural gas.

The presented indices of specific energy content form a basis for the development of static tables of energy content in live biomass components $^{26}$.

24 Лакида П.І., Шевчук О.В., Василишин Р.Д. Енергетичний потенціал лісів Київського Полісся та його стале використання. Монографія. КонсуньШевченківський: ФОП Майдаченко І.В., 2020. 168 с.

${ }_{25}$ Василишин Р.Д. Продуктивність та еколого-енергетичний потенціал лісів Українських Карпат: дис. ... доктора с.-г. наук: 06.03.02. Київ, 2014. 460 с.

26 Лакида П. І. та ін. Нормативи оцінки компонентів надземної фітомаси деревостанів головних лісотвірних порід України. Довідник. КорсуньШевченківський : ФОП В. М. Гавришенко, 2013. 457 с. 
For these reference materials, the inputs for the tables are represented by the following indices: mean diameter, mean height and relative stocking. The adequate results can be obtained using these reference tables only in a certain parametric range, which is determined by quantitative biometric indices of temporary sample plots: mean height from 4 to $28 \mathrm{~m}$, mean diameter $4-32 \mathrm{~cm}$. Fragments of these reference tables for relative stocking of 0.7 are presented in Tables 14-15.

Table 14

Total energy content of live biomass of stems over bark, TJ·ha ${ }^{-1}$

\begin{tabular}{|c|c|c|c|c|c|c|c|c|c|c|c|c|c|}
\hline \multirow{2}{*}{$\begin{array}{c}\text { Mean } \\
\text { diameter, } \\
\text { cm }\end{array}$} & \multicolumn{13}{|c|}{ Mean height, m } \\
\hline & 4 & 6 & 8 & 10 & 12 & 14 & 16 & 18 & 20 & 22 & 24 & 26 & 28 \\
\hline 4 & 0,33 & 0,55 & 0,79 & 1,06 & 1,33 & 1,62 & 1,92 & 2,23 & 2,55 & 2,88 & 3,22 & 3,57 & 3,92 \\
\hline 6 & 0,32 & 0,54 & 0,79 & 1,04 & 1,32 & 1,60 & 1,90 & 2,21 & 2,53 & 2,85 & 3,19 & 3,53 & 3,88 \\
\hline 8 & 0,32 & 0,54 & 0,78 & 1,04 & 1,31 & 1,59 & 1,89 & 2,19 & 2,51 & 2,83 & 3,16 & 3,50 & 3,85 \\
\hline 10 & ,32 & 0,54 & 0,77 & 1,03 & 1,30 & 1,58 & 1,87 & 2,18 & 2,49 & 2,81 & 3,14 & 3,48 & 3,83 \\
\hline 12 & 0,32 & 0,53 & 0,77 & 1,02 & 1,29 & 1,57 & 1,87 & 2,17 & 2,48 & 2,80 & 3,13 & 3,47 & 3,81 \\
\hline 14 & 0,32 & 0,53 & 0,77 & 1,02 & 1,29 & 1,57 & 1,86 & 2,16 & 2,47 & 2,79 & 3,12 & 3,45 & 3,79 \\
\hline 16 & 0,32 & 0,53 & 0,76 & 1,02 & 1,28 & 1,56 & 1,85 & 2,15 & 2,46 & 2,78 & 3,10 & 3,44 & 3,78 \\
\hline 18 & 0,32 & 0,53 & 0,76 & 1,01 & 1,28 & 1,56 & 1,85 & 2,14 & 2,45 & 2,77 & 3,10 & 3,43 & 3,77 \\
\hline 20 & 0,31 & 0,53 & 0,76 & 1,01 & 1,28 & 1,55 & 1,84 & 2,14 & 2,45 & 2,76 & 3,09 & 3,42 & 3,76 \\
\hline 22 & 0,31 & 0,53 & 0,76 & 1,01 & 1,27 & 1,55 & 1,84 & 2,13 & 2,44 & 2,76 & 3,08 & 3,41 & 3,75 \\
\hline 24 & 0,31 & 0,52 & 0,76 & 1,01 & 1,27 & 1,54 & 1,83 & 2,13 & 2,43 & 2,75 & 3,07 & 3,40 & 3,74 \\
\hline 26 & 0,31 & 0,52 & 0,76 & 1,00 & 1,27 & 1,54 & 1,83 & 2,12 & 2,43 & 2,74 & 3,06 & 3,39 & 3,73 \\
\hline 28 & 0,31 & 0,52 & 0,75 & 1,00 & 1,26 & 1,54 & 1,82 & 2,12 & 2,42 & 2,74 & 3,06 & 3,39 & 3,72 \\
\hline
\end{tabular}

Today, in many European countries, wood of branches is recognized as an important additional source of raw materials, which is widely used not only in pulp and paper industry, but also for bioenergy production. In Ukraine, wood and bark are considered non-merchantable raw materials, they are practically not used at all, and mainly remain at harvest plots after logging. Given the global trends in development of renewable energy sources, biomass of branches can become one of the sources of thermal energy in Ukraine, which would require appropriate reference materials to assess their energy content. It should be noted that about $65-75 \%$ of energy accumulated in live biomass of stands is concentrated in stems, and 25-35\% - in components of tree crowns. 
Table 15

Total energy content in live biomass of crown branches, $\mathbf{T J} \cdot \mathbf{h a}^{-1}$

\begin{tabular}{|c|c|c|c|c|c|c|c|c|c|c|c|c|c|}
\hline $\begin{array}{c}\text { Mean } \\
\text { diameter, } \\
\mathbf{c m}\end{array}$ & $\mathbf{9}$ & $\mathbf{6}$ & $\mathbf{8}$ & $\mathbf{1 0}$ & $\mathbf{1 2}$ & $\mathbf{1 4}$ & $\mathbf{1 6}$ & $\mathbf{1 8}$ & $\mathbf{2 0}$ & $\mathbf{2 2}$ & $\mathbf{2 4}$ & $\mathbf{2 6}$ & $\mathbf{2 8}$ \\
\hline 4 & 0,039 & 0,033 & 0,029 & 0,03 & 0,02 & 0,02 & 0,02 & 0,02 & 0,02 & 0,02 & 0,02 & 0,02 & 0,02 \\
\hline 6 & 0,092 & 0,077 & 0,068 & 0,06 & 0,06 & 0,05 & 0,05 & 0,05 & 0,05 & 0,04 & 0,04 & 0,04 & 0,04 \\
\hline 8 & 0,17 & 0,14 & 0,13 & 0,11 & 0,11 & 0,10 & 0,09 & 0,09 & 0,08 & 0,08 & 0,08 & 0,08 & 0,07 \\
\hline 10 & 0,27 & 0,23 & 0,20 & 0,18 & 0,17 & 0,16 & 0,15 & 0,14 & 0,14 & 0,13 & 0,13 & 0,12 & 0,12 \\
\hline 12 & 0,40 & 0,34 & 0,30 & 0,27 & 0,25 & 0,23 & 0,22 & 0,21 & 0,20 & 0,19 & 0,19 & 0,18 & 0,17 \\
\hline 14 & 0,56 & 0,47 & 0,41 & 0,38 & 0,35 & 0,32 & 0,31 & 0,29 & 0,28 & 0,27 & 0,26 & 0,25 & 0,24 \\
\hline 16 & 0,74 & 0,62 & 0,55 & 0,50 & 0,46 & 0,43 & 0,41 & 0,39 & 0,37 & 0,35 & 0,34 & 0,33 & 0,32 \\
\hline 18 & 0,96 & 0,80 & 0,71 & 0,64 & 0,59 & 0,55 & 0,52 & 0,50 & 0,47 & 0,46 & 0,44 & 0,42 & 0,41 \\
\hline 20 & 1,20 & 1,00 & 0,88 & 0,80 & 0,74 & 0,69 & 0,65 & 0,62 & 0,59 & 0,57 & 0,55 & 0,53 & 0,51 \\
\hline 22 & 1,46 & 1,23 & 1,08 & 0,98 & 0,91 & 0,85 & 0,80 & 0,76 & 0,73 & 0,70 & 0,67 & 0,65 & 0,63 \\
\hline 24 & 1,76 & 1,48 & 1,30 & 1,18 & 1,09 & 1,02 & 0,96 & 0,92 & 0,88 & 0,84 & 0,81 & 0,78 & 0,76 \\
\hline 26 & 2,09 & 1,75 & 1,55 & 1,40 & 1,30 & 1,21 & 1,14 & 1,09 & 1,04 & 1,00 & 0,96 & 0,93 & 0,90 \\
\hline 28 & 2,45 & 2,05 & 1,81 & 1,64 & 1,52 & 1,42 & 1,34 & 1,27 & 1,22 & 1,17 & 1,12 & 1,08 & 1,05 \\
\hline
\end{tabular}

Utilization of the abovementioned reference materials can be effective in cases when tree stems of the studied stands are used as an energy resource, and the components of live biomass of crowns will remain at harvesting sites (for further biodegradation) to minimize the negative impact on nutrient circulation between forest stands and soil. Another scenario would be the one when forest management foresees procurement of industrially valuable assortments, thus only harvesting residues (namely branches) can be used for energy purposes.

\section{Information support for assessing primary production of European beech stands in Ukrainian Carpathians}

Net primary production (NPP) is one of the most important indices and bioproductivity components. Assessment of quantitative NPP indices is a necessary precondition for valuation of a number of ecosystem functions of forest plant communities over a certain territory. This index serves as an indicator of environmental feedback on climate change ${ }^{27}$, 28,29 . Its quantitative parameters for European beech stands in Ukrainian

27 Лакида П. І. Фітомаса лісів України. Монографія. Тернопіль : Збруч, 2002. $256 \mathrm{c}$.

${ }^{28}$ Shvidenko A., Schepaschenko D., Nilson S. Modeling Net Primary Production of Northern Eurasia forests: A new method \& new estimate. ECEM'07. Trieste, 2007. P. 485-486.

${ }^{29}$ Shvidenko A., Buksha I., Krakovska S., Lakyda, P. Vulnerability of Ukrainian Forests to Climate Change. Sustainability. 2017. Vol. 9(7). P. 1152-1158. https://doi.org/10.3390/su9071152. 
Carpathians are presented in Table 16. NPP assessment has been carried out in accordance with the methodology proposed by A.Z. Shvidenko ${ }^{30}$.

Table 16

\section{Net primary production of European beech stands} in Ukrainian Carpathians

\begin{tabular}{|c|c|c|c|c|c|c|c|c|}
\hline \multirow[b]{2}{*}{$\begin{array}{l}\text { Species group, } \\
\text { dominant species }\end{array}$} & \multicolumn{7}{|c|}{ NPP by components, Mio tons.year ${ }^{-1}$} & \multirow[b]{2}{*}{ 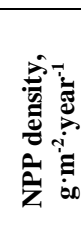 } \\
\hline & 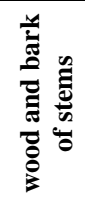 & 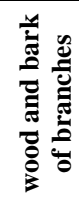 & 总 & $\stackrel{0}{0}$ & 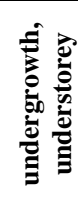 & 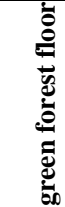 & हूँ & \\
\hline $\begin{array}{c}\text { Hardwood } \\
\text { broadleaves }\end{array}$ & 2,42 & 0,98 & 3,84 & 5,58 & 1,00 & 1,93 & 15,75 & 141 \\
\hline $\begin{array}{c}\text { Including } \\
\text { European beech }\end{array}$ & 1,58 & 0,70 & 2,38 & 3,80 & 0,71 & 1,29 & 10,46 & 1438 \\
\hline
\end{tabular}

The highest values of NPP density in Ukrainian Carpathians are characteristic to European beech stands $-1438 \mathrm{~g} \cdot\left(\mathrm{m}^{2}\right)^{-1} \cdot$ year ${ }^{-1}$, which is $40 \%$ higher than the mean value for Ukraine's forests and $74 \%$ higher than the mean NPP density of Norway spruce stands in the region $\left(822 \mathrm{~g} \cdot\left(\mathrm{m}^{2}\right)^{-1} \cdot\right.$ year $\left.^{-1}\right)$.

To assess the indices of primary production of beech stands in Ukrainian Carpathians, the tools based on representative experimental research data should be applied. In particular, these are static tables for assessment of primary production of tree stems in beech stands (Tables 17-18) and reference tables of dynamics of net primary production of beech stands of different origin (Table 19).

The static reference tables contain information on the volumes of live biomass production by the present growing stock of a stand over bark. They are developed as a function of mean height of a stand $(H)$, mean diameter of a stand $(D)$, and mean width of an annual growth ring.

The values in the tables reflect the live biomass production in tons per $1 \mathrm{~m}^{2}$ of basal area $(G)$. To assess production of stem of a certain stand, the value obtained from the table shall be multiplied by the actual basal area of this stand.

30 Shvidenko A., Schepaschenko D., Nilson S. et al. Semi-empirical models for assessing biological productivity of Northern Eurasian forests. Ecological Modelling. 2007. № 204 (1-2). P. 163-179. 
Table 17

Production of stems of European beech stands in Ukrainian Carpathians $(0,2-2,0)$, tons $\cdot\left(\mathrm{m}^{2} \mathrm{G}\right)^{-1}$

\begin{tabular}{|c|c|c|c|c|c|c|c|}
\hline \multirow{2}{*}{$\mathbf{H}, \mathbf{m}$} & \multirow{2}{*}{$\mathrm{D}, \mathrm{cm}$} & \multicolumn{6}{|c|}{ Annual growth ring width, $\mathbf{m m}$} \\
\hline & & $\mathbf{0 , 2}$ & $\mathbf{0 , 6}$ & 1,0 & 1,4 & 1,6 & 2,0 \\
\hline 1 & 2 & 3 & 4 & 5 & 6 & 7 & 8 \\
\hline 4,0 & 4,0 & 0,0434 & 0,1303 & 0,2171 & 0,3039 & 0,3473 & 0,4342 \\
\hline 5,0 & 4,0 & 0,0536 & 0,1609 & 0,2682 & 0,3755 & 0,4292 & 0,5364 \\
\hline 5,0 & 6,0 & 0,0309 & 0,0929 & 0,1548 & 0,2168 & 0,2477 & 0,3097 \\
\hline 6,0 & 6,0 & 0,0369 & 0,1106 & 0,1843 & 0,2581 & 0,2949 & 0,3687 \\
\hline 6,0 & 8,0 & 0,0260 & 0,0780 & 0,1300 & 0,1820 & 0,2080 & 0,2601 \\
\hline 7,0 & 7,0 & 0,0354 & 0,1061 & 0,1769 & 0,2476 & 0,2830 & 0,3537 \\
\hline 7,0 & 9,0 & 0,0263 & 0,0788 & 0,1314 & 0,1840 & 0,2102 & 0,2628 \\
\hline 8,0 & 8,0 & 0,0343 & 0,1029 & 0,1715 & 0,2402 & 0,2745 & 0,3431 \\
\hline 8,0 & 12,0 & 0,0215 & 0,0646 & 0,1076 & 0,1506 & 0,1721 & 0,2151 \\
\hline 9,0 & 8,0 & 0,0384 & 0,1153 & 0,1922 & 0,2690 & 0,3075 & 0,3843 \\
\hline 9,0 & 12,0 & 0,0241 & 0,0723 & 0,1206 & 0,1689 & 0,1930 & 0,2412 \\
\hline 9,0 & 14,0 & 0,0203 & 0,0609 & 0,1015 & 0,1421 & 0,1623 & 0,2030 \\
\hline 10,0 & 10,0 & 0,0328 & 0,0986 & 0,1643 & 0,2300 & 0,2628 & 0,3286 \\
\hline 10,0 & 14,0 & 0,0225 & 0,0675 & 0,1124 & 0,1575 & 0,1799 & 0,2249 \\
\hline 10,0 & 16,0 & 0,0194 & 0,0582 & 0,0970 & 0,1358 & 0,1552 & 0,1940 \\
\hline 12,0 & 12,0 & 0,0319 & 0,0957 & 0,1595 & 0,2233 & 0,2552 & 0,3190 \\
\hline 12,0 & 16,0 & 0,0232 & 0,0696 & 0,1159 & 0,1623 & 0,1854 & 0,2318 \\
\hline 14,0 & 14,0 & 0,0312 & 0,0937 & 0,1561 & 0,2186 & 0,2498 & 0,3123 \\
\hline 14,0 & 18,0 & 0,0237 & 0,0711 & 0,1185 & 0,1659 & 0,1896 & 0,2370 \\
\hline 14,0 & 20,0 & 0,0211 & 0,0634 & 0,1057 & 0,1480 & 0,1691 & 0,2113 \\
\hline 16,0 & 18,0 & 0,0270 & 0,0810 & 0,1351 & 0,1891 & 0,2161 & 0,2702 \\
\hline 16,0 & 22,0 & 0,0217 & 0,0652 & 0,1087 & 0,1522 & 0,1739 & 0,2174 \\
\hline 18,0 & 20,0 & 0,0270 & 0,0811 & 0,1353 & 0,1894 & 0,2164 & 0,2705 \\
\hline 18,0 & 24,0 & 0,0222 & 0,0667 & 0,1112 & 0,1557 & 0,1779 & 0,2224 \\
\hline 20,0 & 20,0 & 0,0300 & 0,0900 & 0,1500 & 0,2100 & 0,2400 & 0,3000 \\
\hline 20,0 & 28,0 & 0,0210 & 0,0628 & 0,1047 & 0,1466 & 0,1676 & 0,2094 \\
\hline 20,0 & 32,0 & 0,0182 & 0,0546 & 0,0909 & 0,1273 & 0,1455 & 0,1819 \\
\hline 22,0 & 24,0 & 0,0271 & 0,0813 & 0,1356 & 0,1898 & 0,2169 & 0,2711 \\
\hline 22,0 & 32,0 & 0,0200 & 0,0600 & 0,1000 & 0,1399 & 0,1600 & 0,1999 \\
\hline 22,0 & 40,0 & 0,0159 & 0,0475 & 0,0792 & 0,1108 & 0,1266 & 0,1583 \\
\hline 24,0 & 28,0 & 0,0251 & 0,0753 & 0,1255 & 0,1756 & 0,2007 & 0,2508 \\
\hline 24,0 & 36,0 & 0,0192 & 0,0578 & 0,0963 & 0,1349 & 0,1541 & 0,1927 \\
\hline 24,0 & 44,0 & 0,0156 & 0,0469 & 0,0782 & 0,1095 & 0,1252 & 0,1565 \\
\hline 26,0 & 28,0 & 0,0271 & 0,0814 & 0,1358 & 0,1901 & 0,2172 & 0,2715 \\
\hline 26,0 & 36,0 & 0,0208 & 0,0626 & 0,1043 & 0,1461 & 0,1669 & 0,2086 \\
\hline 26,0 & 44,0 & 0,0169 & 0,0508 & 0,0847 & 0,1186 & 0,1356 & 0,1695 \\
\hline
\end{tabular}


Continuation of Table 17

\begin{tabular}{|c|c|c|c|c|c|c|c|}
\hline $\mathbf{1}$ & $\mathbf{2}$ & $\mathbf{3}$ & $\mathbf{4}$ & $\mathbf{5}$ & $\mathbf{6}$ & $\mathbf{7}$ & $\mathbf{8}$ \\
\hline 28,0 & 28,0 & 0,0292 & 0,0877 & 0,1461 & 0,2045 & 0,2337 & 0,2922 \\
\hline 28,0 & 36,0 & 0,0225 & 0,0674 & 0,1123 & 0,1572 & 0,1797 & 0,2246 \\
\hline 28,0 & 44,0 & 0,0182 & 0,0548 & 0,0912 & 0,1277 & 0,1459 & 0,1825 \\
\hline 28,0 & 52,0 & 0,0154 & 0,0462 & 0,0769 & 0,1076 & 0,1230 & 0,1537 \\
\hline 28,0 & 60,0 & 0,0133 & 0,0399 & 0,0665 & 0,0931 & 0,1063 & 0,1329 \\
\hline 30,0 & 28,0 & 0,0313 & 0,0939 & 0,1564 & 0,2189 & 0,2503 & 0,3128 \\
\hline 30,0 & 36,0 & 0,0241 & 0,0722 & 0,1203 & 0,1684 & 0,1925 & 0,2406 \\
\hline 30,0 & 44,0 & 0,0195 & 0,0586 & 0,0977 & 0,1369 & 0,1564 & 0,1955 \\
\hline 30,0 & 52,0 & 0,0165 & 0,0494 & 0,0824 & 0,1154 & 0,1318 & 0,1648 \\
\hline 30,0 & 60,0 & 0,0143 & 0,0428 & 0,0712 & 0,0997 & 0,1140 & 0,1425 \\
\hline 30,0 & 72,0 & 0,0119 & 0,0356 & 0,0593 & 0,0830 & 0,0949 & 0,1187 \\
\hline 34,0 & 38,0 & 0,0258 & 0,0773 & 0,1288 & 0,1803 & 0,2061 & 0,2576 \\
\hline 34,0 & 50,0 & 0,0194 & 0,0583 & 0,0972 & 0,1361 & 0,1555 & 0,1944 \\
\hline 34,0 & 62,0 & 0,0156 & 0,0469 & 0,0782 & 0,1094 & 0,1251 & 0,1563 \\
\hline 34,0 & 74,0 & 0,0131 & 0,0393 & 0,0655 & 0,0917 & 0,1048 & 0,1310 \\
\hline 38,0 & 42,0 & 0,0260 & 0,0779 & 0,1298 & 0,1817 & 0,2077 & 0,2596 \\
\hline 38,0 & 54,0 & 0,0201 & 0,0603 & 0,1005 & 0,1407 & 0,1607 & 0,2010 \\
\hline 38,0 & 66,0 & 0,0164 & 0,0492 & 0,0821 & 0,1149 & 0,1314 & 0,1642 \\
\hline 38,0 & 78,0 & 0,0139 & 0,0418 & 0,0696 & 0,0974 & 0,1113 & 0,1391 \\
\hline 38,0 & 84,0 & 0,0129 & 0,0388 & 0,0647 & 0,0905 & 0,1035 & 0,1294 \\
\hline 42,0 & 64,0 & 0,0187 & 0,0562 & 0,0937 & 0,1311 & 0,1499 & 0,1873 \\
\hline 42,0 & 76,0 & 0,0158 & 0,0469 & 0,0789 & 0,1105 & 0,1263 & 0,1579 \\
\hline 42,0 & 82,0 & 0,0147 & 0,0440 & 0,0733 & 0,1026 & 0,1173 & 0,1465 \\
\hline 42,0 & 94,0 & 0,0128 & 0,0385 & 0,0642 & 0,0898 & 0,1026 & 0,1283 \\
\hline 42,0 & 100,0 & 0,0121 & 0,0362 & 0,0604 & 0,0846 & 0,0966 & 0,1208 \\
\hline 42,0 & 106,0 & 0,0114 & 0,0343 & 0,0571 & 0,0800 & 0,0914 & 0,1142 \\
\hline
\end{tabular}

For practical application of reference tables, the width of an annual growth ring should be calculated as the arithmetic mean of measurements of the annual growth ring widths for 25-30 metering trees in the range $\mathrm{D} \pm 2-4 \mathrm{~cm}$. The measurements should be carried out using an increment borer.

Table 18

Production of stems of European beech stands in Ukrainian Carpathians $(2,4-4,2)$, tons $\cdot\left(\mathrm{m}^{2} \mathrm{G}\right)^{-1}$

\begin{tabular}{|c|c|c|c|c|c|c|c|}
\hline \multirow{2}{*}{ H, $\mathbf{m}$} & \multirow{2}{*}{$\mathbf{D}, \mathbf{c m}$} & \multicolumn{7}{|c|}{ Annual growth ring width, mm } \\
\cline { 3 - 8 } & & $\mathbf{2 , 4}$ & $\mathbf{2 , 8}$ & $\mathbf{3 , 0}$ & $\mathbf{3 , 4}$ & $\mathbf{3 , 8}$ & $\mathbf{4 , 2}$ \\
\hline $\mathbf{1}$ & $\mathbf{2}$ & $\mathbf{3}$ & $\mathbf{4}$ & $\mathbf{5}$ & $\mathbf{6}$ & $\mathbf{7}$ & $\mathbf{8}$ \\
\hline 4,0 & 4,0 & 0,5210 & - & - & - & - & - \\
\hline 5,0 & 4,0 & 0,6437 & 0,7510 & 0,8046 & 0,9120 & - & - \\
\hline
\end{tabular}


Continuation of Table 18

\begin{tabular}{|c|c|c|c|c|c|c|c|}
\hline 1 & 2 & 3 & 4 & 5 & 6 & 7 & 8 \\
\hline 5,0 & 6,0 & 0,3715 & 0,4335 & 0,4644 & 0,5264 & - & - \\
\hline 6,0 & 6,0 & 0,4424 & 0,5161 & 0,5530 & 0,6267 & 0,7005 & 0,7742 \\
\hline 6,0 & 8,0 & 0,3120 & 0,3641 & 0,3901 & 0,4421 & 0,4941 & 0,5461 \\
\hline 7,0 & 7,0 & 0,4245 & 0,4952 & 0,5306 & 0,6014 & 0,6721 & 0,7429 \\
\hline 7,0 & 9,0 & 0,3154 & 0,3679 & 0,3942 & 0,4467 & 0,4993 & 0,5518 \\
\hline 8,0 & 8,0 & 0,4117 & 0,4803 & 0,5146 & 0,5832 & 0,6519 & 0,7205 \\
\hline 8,0 & 12,0 & 0,2582 & 0,3012 & 0,3227 & 0,3657 & 0,4088 & 0,4518 \\
\hline 9,0 & 8,0 & 0,4611 & 0,5380 & 0,5764 & 0,6533 & 0,7301 & 0,8070 \\
\hline 9,0 & 12,0 & 0,2895 & 0,3377 & 0,3619 & 0,4101 & 0,4583 & 0,5066 \\
\hline 9,0 & 14,0 & 0,2435 & 0,2842 & 0,3044 & 0,3451 & 0,3856 & 0,4262 \\
\hline 10,0 & 10,0 & 0,3943 & 0,4600 & 0,4929 & 0,5586 & 0,6243 & 0,6900 \\
\hline 10,0 & 14,0 & 0,2699 & 0,3149 & 0,3374 & 0,3824 & 0,4273 & 0,4723 \\
\hline 10,0 & 16,0 & 0,2328 & 0,2716 & 0,2880 & 0,3298 & 0,3686 & 0,4074 \\
\hline 12,0 & 12,0 & 0,3829 & 0,4467 & 0,4786 & 0,5424 & 0,6062 & 0,6700 \\
\hline 12,0 & 16,0 & 0,2782 & 0,3246 & 0,3478 & 0,3941 & 0,4405 & 0,4868 \\
\hline 14,0 & 14,0 & 0,3747 & 0,4372 & 0,4684 & 0,5309 & 0,5933 & 0,6557 \\
\hline 14,0 & 18,0 & 0,2844 & 0,3317 & 0,3554 & 0,4029 & 0,4503 & 0,4977 \\
\hline 14,0 & 20,0 & 0,2536 & 0,2959 & 0,3170 & 0,3593 & 0,4015 & 0,4438 \\
\hline 16,0 & 18,0 & 0,3241 & 0,3782 & 0,4052 & 0,4592 & 0,5132 & 0,5673 \\
\hline 16,0 & 22,0 & 0,2609 & 0,3044 & 0,3261 & 0,3696 & 0,4131 & 0,4566 \\
\hline 18,0 & 20,0 & 0,3246 & 0,3787 & 0,4058 & 0,4599 & 0,5140 & 0,5681 \\
\hline 18,0 & 24,0 & 0,2669 & 0,3114 & 0,3336 & 0,3781 & 0,4226 & 0,4671 \\
\hline 20,0 & 20,0 & 0,3600 & 0,4200 & 0,4500 & 0,5101 & 0,5701 & 0,6301 \\
\hline 20,0 & 28,0 & 0,2513 & 0,2932 & 0,3142 & 0,3560 & 0,3979 & 0,4399 \\
\hline 20,0 & 32,0 & 0,2183 & 0,2546 & 0,2728 & 0,3092 & 0,3456 & 0,3819 \\
\hline 22,0 & 24,0 & 0,3253 & 0,3795 & 0,4066 & 0,4608 & 0,5151 & 0,5693 \\
\hline 22,0 & 32,0 & 0,2399 & 0,2799 & 0,2999 & 0,3399 & 0,3799 & 0,4198 \\
\hline 22,0 & 40,0 & 0,1900 & 0,2216 & 0,2375 & 0,2691 & 0,3008 & 0,3325 \\
\hline 24,0 & 28,0 & 0,3010 & 0,3512 & 0,3763 & 0,4264 & 0,4766 & 0,5268 \\
\hline 24,0 & 36,0 & 0,2312 & 0,2697 & 0,2890 & 0,3275 & 0,3661 & 0,4046 \\
\hline 24,0 & 44,0 & 0,1877 & 0,2190 & 0,2346 & 0,2659 & 0,2972 & 0,3285 \\
\hline 26,0 & 28,0 & 0,3258 & 0,3802 & 0,4073 & 0,4616 & 0,5159 & 0,5702 \\
\hline 26,0 & 36,0 & 0,2504 & 0,2921 & 0,3130 & 0,3547 & 0,3964 & 0,4381 \\
\hline 26,0 & 44,0 & 0,2033 & 0,2372 & 0,2542 & 0,2881 & 0,3219 & 0,3559 \\
\hline 28,0 & 28,0 & 0,3506 & 0,4090 & 0,4383 & 0,4967 & 0,5552 & 0,6135 \\
\hline 28,0 & 36,0 & 0,2695 & 0,3145 & 0,3369 & 0,3818 & 0,4267 & 0,4716 \\
\hline 28,0 & 44,0 & 0,2189 & 0,2555 & 0,2737 & 0,3102 & 0,3467 & 0,3832 \\
\hline 28,0 & 52,0 & 0,1845 & 0,2153 & 0,2307 & 0,2614 & 0,2921 & 0,3229 \\
\hline 28,0 & 60,0 & 0,1595 & 0,1861 & 0,1994 & 0,2260 & 0,2526 & 0,2792 \\
\hline 30,0 & 28,0 & 0,3754 & 0,4380 & 0,4692 & 0,5318 & 0,5944 & 0,6569 \\
\hline
\end{tabular}


End of Table 18

\begin{tabular}{|c|c|c|c|c|c|c|c|}
\hline $\mathbf{1}$ & $\mathbf{2}$ & $\mathbf{3}$ & $\mathbf{4}$ & $\mathbf{5}$ & $\mathbf{6}$ & $\mathbf{7}$ & $\mathbf{8}$ \\
\hline 30,0 & 36,0 & 0,2887 & 0,3367 & 0,3608 & 0,4089 & 0,4570 & 0,5051 \\
\hline 30,0 & 44,0 & 0,2346 & 0,2737 & 0,2932 & 0,3323 & 0,3714 & 0,4105 \\
\hline 30,0 & 52,0 & 0,1977 & 0,2307 & 0,2471 & 0,2801 & 0,3130 & 0,3460 \\
\hline 30,0 & 60,0 & 0,1710 & 0,1995 & 0,2137 & 0,2422 & 0,2707 & 0,2992 \\
\hline 30,0 & 72,0 & 0,1424 & 0,1661 & 0,1780 & 0,2017 & 0,2254 & 0,2492 \\
\hline 34,0 & 38,0 & 0,3091 & 0,3607 & 0,3864 & 0,4380 & 0,4895 & 0,5410 \\
\hline 34,0 & 50,0 & 0,2333 & 0,2721 & 0,2915 & 0,3304 & 0,3693 & 0,4082 \\
\hline 34,0 & 62,0 & 0,1876 & 0,2189 & 0,2345 & 0,2658 & 0,2971 & 0,3283 \\
\hline 34,0 & 74,0 & 0,1572 & 0,1834 & 0,1965 & 0,2227 & 0,2489 & 0,2751 \\
\hline 38,0 & 42,0 & 0,3116 & 0,3635 & 0,3894 & 0,4413 & 0,4933 & 0,5452 \\
\hline 38,0 & 54,0 & 0,2412 & 0,2813 & 0,3015 & 0,3416 & 0,3818 & 0,4220 \\
\hline 38,0 & 66,0 & 0,1971 & 0,2299 & 0,2463 & 0,2792 & 0,3120 & 0,3449 \\
\hline 38,0 & 78,0 & 0,1670 & 0,1948 & 0,2087 & 0,2365 & 0,2643 & 0,2922 \\
\hline 38,0 & 84,0 & 0,1552 & 0,1811 & 0,1940 & 0,2199 & 0,2457 & 0,2716 \\
\hline 42,0 & 64,0 & 0,2248 & 0,2623 & 0,2810 & 0,3184 & 0,3559 & 0,3933 \\
\hline 42,0 & 70,0 & 0,2056 & 0,2399 & 0,2570 & 0,2912 & 0,3255 & 0,3598 \\
\hline 42,0 & 76,0 & 0,1895 & 0,2211 & 0,2369 & 0,2685 & 0,3000 & 0,3316 \\
\hline 42,0 & 82,0 & 0,1759 & 0,2052 & 0,2198 & 0,2491 & 0,2785 & 0,3078 \\
\hline 42,0 & 88,0 & 0,1641 & 0,1915 & 0,2052 & 0,2325 & 0,2599 & 0,2872 \\
\hline 42,0 & 94,0 & 0,1539 & 0,1796 & 0,1924 & 0,2181 & 0,2437 & 0,2694 \\
\hline 42,0 & 100,0 & 0,1450 & 0,1692 & 0,1812 & 0,2054 & 0,2296 & 0,2538 \\
\hline 42,0 & 106,0 & 0,1371 & 0,1600 & 0,1714 & 0,1942 & 0,2171 & 0,2399 \\
\hline
\end{tabular}

Dynamic tables that reflect the trends of NPP change in modal stands of different site index classes are the basis for the forecast assessment of net primary production of forest plant communities. The relevant reference tables for European beech stands of the region are proposed in this research (Table 19).

Table 19

Dynamics of net primary production of European beech stands of different origin in Ukrainian Carpathians, $g \cdot\left(\mathrm{m}^{2}\right)^{-1} \cdot \mathrm{year}^{-1}$

\begin{tabular}{|c|c|c|c|c|c|c|}
\hline \multirow{2}{*}{$\begin{array}{l}\text { Age, } \\
\text { years }\end{array}$} & \multicolumn{6}{|c|}{ Site index class } \\
\hline & $\mathbf{I}^{\mathbf{b}}$ & $\mathbf{I}^{\mathbf{a}}$ & I & II & III & IV \\
\hline 1 & 2 & 3 & 4 & 5 & 6 & 7 \\
\hline \multicolumn{7}{|c|}{ pure stands of natural origin } \\
\hline 10 & 1093 & 937 & 794 & 653 & 517 & 414 \\
\hline 20 & 1624 & 1461 & 1279 & 1085 & 881 & 705 \\
\hline 30 & 1848 & 1699 & 1521 & 1317 & 1097 & 889 \\
\hline 40 & 1903 & 1778 & 1616 & 1428 & 1222 & 1010 \\
\hline 50 & 1873 & 1770 & 1630 & 1471 & 1299 & 1099 \\
\hline
\end{tabular}


Continuation of Table 19

\begin{tabular}{|c|c|c|c|c|c|c|}
\hline & & & & & \multirow[b]{2}{*}{7} \\
\hline 1 & 2 & 3 & 4 & 5 & 6 & \\
\hline 860 & 1844 & 1754 & 1626 & 1477 & 1307 & 1123 \\
\hline 70 & 1782 & 1707 & 1598 & 1469 & 1315 & 1149 \\
\hline 80 & 1717 & 1659 & 1568 & 1457 & 1319 & 1168 \\
\hline 90 & 1661 & 1616 & 1541 & 1448 & 1323 & 1188 \\
\hline 100 & 1614 & 1584 & 1523 & 1444 & 1331 & 1208 \\
\hline 110 & 1566 & 1545 & 1493 & 1424 & 1327 & 1214 \\
\hline 120 & 1535 & 1525 & 1481 & 1420 & 1333 & 1226 \\
\hline \multicolumn{7}{|c|}{ mixed stands of natural origin } \\
\hline 10 & 1008 & 859 & 715 & 578 & 469 & 374 \\
\hline 20 & 1614 & 1444 & 1255 & 1048 & 865 & 689 \\
\hline 30 & 1889 & 1731 & 1541 & 1323 & 1109 & 895 \\
\hline 40 & 1970 & 1834 & 1663 & 1461 & 1248 & 1028 \\
\hline 50 & 1945 & 1832 & 1691 & 1523 & 1329 & 1117 \\
\hline 60 & 1911 & 1812 & 1679 & 1519 & 1341 & 1145 \\
\hline 70 & 1840 & 1760 & 1644 & 1505 & 1349 & 1168 \\
\hline 80 & 1766 & 1703 & 1606 & 1487 & 1349 & 1186 \\
\hline 90 & 1701 & 1653 & 1572 & 1471 & 1352 & 1202 \\
\hline 100 & 1646 & 1614 & 1545 & 1461 & 1356 & 1218 \\
\hline 110 & 1592 & 1570 & 1517 & 1438 & 1343 & 1220 \\
\hline 120 & 1558 & 1545 & 1503 & 1432 & 1339 & 1232 \\
\hline \multicolumn{7}{|c|}{ mixed stands of artificial origin } \\
\hline 10 & 851 & 749 & 651 & 570 & 489 & 406 \\
\hline 20 & 1446 & 1335 & 1202 & 1077 & 935 & 780 \\
\hline 30 & 1731 & 1634 & 1505 & 1366 & 1204 & 1014 \\
\hline 40 & 1822 & 1752 & 1642 & 1507 & 1343 & 1145 \\
\hline 50 & 1812 & 1768 & 1685 & 1560 & 1408 & 1214 \\
\hline 60 & 1760 & 1723 & 1651 & 1545 & 1410 & 1236 \\
\hline 70 & 1687 & 1667 & 1608 & 1521 & 1402 & 1244 \\
\hline 80 & 1618 & 1610 & 1566 & 1493 & 1390 & 1251 \\
\hline 90 & 1556 & 1560 & 1529 & 1471 & 1380 & 1255 \\
\hline 100 & 1507 & 1521 & 1503 & 1455 & 1374 & 1263 \\
\hline 110 & 1459 & 1479 & 1467 & 1430 & 1362 & 1265 \\
\hline 120 & 1428 & 1457 & 1451 & 1422 & 1362 & 1267 \\
\hline
\end{tabular}

\section{CONCLUSIONS}

At present, Ukrainian Carpathians have significant reserves of forest resources while forming a unique natural complex. Research of ecological functions of the Carpathian forests, which affect the climate and hydrological resources of a significant part of Eurasian continent, has become a prerequisite for transition to sustainable forestry in the region and Ukraine's compliance with the declared international 
agreements related to environmental issues. At the same time, the relevance of recent research has long gone beyond regional issues and became global.

As a result of the research, it was established that beech stands in Ukrainian Carpathians cover an area of over 2 million hectares, where about 580 million $\mathrm{m}^{3}$ of growing stock is located. Almost $57 \%$ of beech forests with a growing stock of $129.1 \mathrm{Mio}^{3}$ are concentrated in Zakarpattia region, another $30 \%$ in Ivano-Frankivsk and Lviv regions. In general, European beech stands in Ukrainian Carpathians cover $33.5 \%$ of the forested area in the region. European beech forms pure and mixed stands of natural and artificial origin, which grow in moist, fairly rich and rich conditions.

In beech stands of the region the amount of accumulated biomass exceeds 220 Mio tons, its density reaches $30 \mathrm{~kg} \cdot\left(\mathrm{m}^{2}\right)^{-1}$. In Zakarpattia region the mentioned index equals $35,9 \mathrm{~kg} \cdot\left(\mathrm{m}^{2}\right)^{-1}$, in Bukovyna $32,3 \mathrm{~kg} \cdot\left(\mathrm{m}^{2}\right)^{-1}$, in Lviv and Precarpathians $-30,8$ and $30,2 \mathrm{~kg} \cdot\left(\mathrm{m}^{2}\right)^{-1}$ correspondingly.

The basis for forecasting biomass reserves of mountain beech forests are reference tables of bioproductivity dynamics, developed on the site index scale basis. At the same time, to assess the energy potential of woody bioomass, reference materials of energy content in live biomass components are proposed within this research.

Net primary production of the studied stands in the region is over 10 Mio tons of organic matter per annuum. The net primary production density in beech stands of Ukrainian Carpathians is $1438 \mathrm{~g} \cdot\left(\mathrm{m}^{2}\right)^{-1} \cdot \mathrm{year}^{-1}$, which is $40 \%$ higher than the mean for Ukraine's forests in general. Static tables of production of stems and reference materials of dynamics of net primary production for beech stands of different origin should be used to evaluate the production of the forest stands.

\section{SUMMARY}

In the modern realities of human-nature interaction in the context of sustainable social development, forest plant communities play an important role, which is an critical factor in stabilizing the environment in the context of global climate change. They are also an important source of renewable natural resources.

In the course of the research, an analytical assessment of silvicultural and biometric characteristics of European beech forests in Ukrainian Carpathians was carried out. This allowed to assess their current state 
and determine a set of factors that shape the features of formation of biomass and primary production potential.

The components of beech forests bioproductivity, namely their quantitative indices of live biomass and primary production have been established. A system of reference and information support for assessing and forecasting indices of biomass and production of beech stands in Ukrainian Carpathians is proposed. The system will serve as a tool for organizing the sustainable use of forest resources. The obtained results will provide an information basis for introduction of close to nature mountain forestry.

\section{References}

1. Василишин Р.Д. Ліси Українських Карпат: особливості росту, біологічна та енергетична продуктивність. Монографія. Київ : ТОВ «ЦП «Компринт», 2016. 418 с.

2. Василишин Р. Д. Еколого-енергетичний потенціал лісів Українських Карпат та його стале використання. Монографія. Київ : ТОВ «ЦП «Компринт», 2018. 303 с.

3. Пастернак П.С. Горные леса Украинской. Москва : Лесн. пром-сть, 1979. С. 105-118.

4. Генсірук С.А. Ліси Українських Карпат та їх використання. Київ : Урожай, 1964. 290 с.

5. Генсірук С.А. Ліси України. Київ : Наук. думка, 1992. 408 с.

6. Генсірук С.А., Нижник М. С., Копій Л. І. Ліси Західного регіону України. Львів : Атлас, 1998. 408 с.

7. Стойко С.М. Наслідки антропогенної трансформації лісових екосистем Карпат та шляхи елімінації шкідливих екологічних процесів. Украӥнський ліс. 1993. № 2. С. 11-17.

8. Стойко С.М. Причини катастрофічних паводків у Закарпатті та системи екологічних профілактичних заходів їх попередження. Український ботанічний журнал. 2000. Т. 57, № 1. С. 11-20.

9. Олійник В.С. Методичні особливості вивчення і оцінки гідрологічної ролі гірських лісів Карпат. Науковий вісник Національного аграрного університету. 2000. Вип. 25. С. 159-166.

10. Сабан Я.А. Продуктивность и возобновление леса в горных условиях. Львов : Выща школа, 1988. 144 с.

11.Смаглюк К.К. Оценка экологических последствий хозяйственного преобразования горных лесов Карпат. Лесоведение. 1978. № 2. C. 3-9. 
12. Калуцький І.Ф. Вітровали на північно-східному макросхилі в Українських Карпатах. Монографія. Львів : Манускрипт, 1998. 204 с.

13. Лакида П.І., Бокоч В.В., Василишин Р.Д., Терентьєв А.Ю. Біопродуктивність лісових фітоценозів Карпатського національного природного парку. Монографія. Корсунь-Шевченківський : ФОП Гавришенко В. М., 2015. 154 с.

14.Каганяк Ю.Й. Структура поколінь лісу різновікових букових деревостанів північно-східного мегасхилу Карпат. Наукові праці лісівничої академії наук України. 2011. Вип. 9. С. 118-120.

15.Парпан B.I. Концептуальні засади гірського лісознавства та лісівництва. Науковий вісник Національного лісотехнічного університету України. 2013. Вип. 23.5. С. 22-28.

16.Василишин Р.Д., Домашовець Г.С., Василишин О.М. Біопродуктивність та депонований вуглець штучних модальних букових деревостанів Українських Карпат. Науковий вісник Національного лісотехнічного університету. 2013. Вип. 23.11. C. $14-19$.

17.Швиденко А.3., Лакида П.І., Щепащенко Д.Г., Василишин Р.Д., Марчук Ю.М. Вуглець, клімат та землеуправління в Україні: лісовий сектор. Монографія. Корсунь-Шевченківський : ФОП Гавришенко В. М., 2014. 283 с.

18.Василишин Р.Д. Ліси Українських Карпат: особливості росту, біологічна та енергетична продуктивність. Монографія. Київ : ТОВ «ЦП «Компринт», 2016. 418 с.

19.Lakyda P., Geletukha G., Vasylyshyn R. et. all. Energy potential of biomass in Ukraine. Kyiv : Publishing Center of NUBiP of Ukraine, 2011. 28 p.

20. Довідник лісового фонду України [укладений спеціалістами виробничо-технологічного відділу ВО «Укрдержліспроект» за матеріалами державного обліку лісів станом на 01.01.2011р.]. Ірпінь: ВО «Укрдержліспроект», 2012. 130 с.

21.Швиденко А.3., Щепащенко Д.Г., Нильсон С., Булуй Ю.И. Таблицы и модели хода роста и продуктивности насаждений основных лесообразующих пород Северной Евразии. Москва : ОАО «Московская типография № 6», 2008. 887 с.

22.Швиденко А.3., Лакида П.І., Щепащенко Д.Г., Василишин Р.Д., Марчук Ю.М. Вуглець, клімат та землеуправління в Україні: лісовий сектор. Монографія. Корсунь-Шевченківський : ФОП Гавришенко В. М., 2014. 283 с. 
23. Василишин Р.Д. Ліси Українських Карпат: особливості росту, біологічна та енергетична продуктивність. Монографія. Київ : ТОВ «ЦП «Компринт», 2016. 418 с.

24. Лакида П.І., Шевчук О.В., Василишин Р.Д. Енергетичний потенціал лісів Київського Полісся та його стале використання. Монографія. Консунь-Шевченківський: ФОП Майдаченко I.В., 2020. 168 c.

25. Василишин Р.Д. Продуктивність та еколого-енергетичний потенціал лісів Українських Карпат: дис. ... доктора с.-г. наук: 06.03.02. Київ, 2014. 460 с.

26. Лакида П. І. та ін. Нормативи оцінки компонентів надземної фітомаси деревостанів головних лісотвірних порід України. Довідник. Корсунь-Шевченківський : ФОП В. М. Гавришенко, 2013. 457 c.

27. Лакида П. І. Фітомаса лісів України. Монографія. Тернопіль : Збруч, 2002. $256 \mathrm{c}$.

28. Shvidenko A., Schepaschenko D., Nilson S. Modeling Net Primary Production of Northern Eurasia forests: A new method \& new estimate. ECEM'07. Trieste, 2007. P. 485-486.

29. Shvidenko A., Buksha I., Krakovska S., Lakyda, P. Vulnerability of Ukrainian Forests to Climate Change. Sustainability. 2017. Vol. 9 (7). P. 1152-1158. https://doi.org/10.3390/su9071152.

30. Shvidenko A., Schepaschenko D., Nilson S. et al. Semi-empirical models for assessing biological productivity of Northern Eurasian forests. Ecological Modelling. 2007. № 204 (1-2). P. 163-179.

\section{Information about the authors: Vasylyshyn Roman Dmytrovych, Doctor of Agricultural Sciences,} Professor at the Forest Mensuration and Forest Management Department, National University of Life and Environmental Sciences of Ukraine Heroyiv Oborony st., 15, Kyiv, 03041, Ukraine

\section{Lakyda Ivan Petrovych,} Candidate of Agricultural Sciences, Associate Professor at the Forest Mensuration and Forest Management Department, National University of Life and Environmental Sciences of Ukraine Heroyiv Oborony st., 15, Kyiv, 03041, Ukraine 